\title{
Access to Housing through Cooperatives: Potentials and Challenges from Tanzania
}

\author{
Nguluma Huba \\ Institute of Human settlements studies \\ Ardhi University \\ Dar es Salaam
}

\begin{abstract}
Access to housing in urban areas has been among the biggest challenges in Tanzania. Leaving aside other approaches to access housing, cooperative housing societies features in both developed and developing countries, though with varying experiences. The cooperatives and community based groups are widely accepted as an important approach for housing middle and even some low-income families at a reasonable cost.

The co-operative movement in the housing sector in Tanzania came up as a result of the international idea in the late 1960s of promoting home ownership through housing co-operatives for low-income families. Even though the number of Housing Cooperatives showed a steady increase in the 1970s, the decades of 1980s and 1990 s revealed a decreasing trend in both number of Cooperative Societies and members in Tanzania. Following the collapse of Tanzania Housing bank (THB) in 1995, financing of the cooperative housing projects became difficulty. From late 1990s to date there have been isolated donor community-initiated cooperative housing projects with less government participation. The main driving assumption here is that despite the seemingly failure of housing cooperative initiatives in the country, the same societies are still viewed as instrumental vehicles for facilitating the poor to access decent housing especially in the urban context. This paper pools together the key observations emerging from the four case study housing co-operative projects reflecting upon policy frameworks that are directly related to housing co-operative development in Tanzania. Further, it highlights on the challenges and potential qualities of housing cooperative societies as vehicles for facilitating their member's access to decent housing. The cases studied reveal that there is a need to maintain a viable cooperative housing movement as a model of housing production. The government and other stakeholders should promote and support in bringing together the existing housing cooperatives, establish an umbrella-housing cooperative with the functions of networking, facilitating primary and secondary housing cooperative societies in capacity building and soliciting alternative financing sources for affordable housing through networking. It is hereby maintained that housing cooperatives have a role to play if marginalization of the majority urban residents on access to housing is to be avoided in the new economic environment.
\end{abstract}

Keywords: Housing, Cooperatives, financing, Low income households

\section{INTRODUCTION}

The idea of establishing cooperatives in Tanzania has a long history that dates back since early 1920s when Coffee Growers in Kilimanjaro formed a Cooperative Union to deal with problems of the then expanding coffee production in the region. As far as housing sector is concerned, Housing Cooperatives were initiated in early 1960s during the period when cooperative initiatives were highly advocated with substantial backing of the Ujamaa Policy. Under this policy, mutual and self-help cooperative living and working were supported by the government. These efforts were manifested in the establishment of the Central Cooperative Union namely the Cooperative Union of Tanzania (CUT), establishment of Ministries and Departments to deal with Cooperative matters, putting in place mechanisms for financing housing cooperatives such as the establishment of the then THB that provided soft loans for both urban and rural cooperative housing projects, streamlining land and title acquisition to Cooperative members and developing manuals to guide the establishment of Cooperative Unions. These efforts were concretized by enacting the Tanzanian Cooperative Act Number 27 of 1968 as revised in 1991 and subsequently the Cooperative Societies Rules under the Government Notice Number 408 of 1991. This Act was further revised in 2003. All these efforts were geared towards facilitating effective formation and operation of Housing Cooperative initiatives and were largely spearheaded by the government. 
The co-operative movement in the housing sector in Tanzania came up as a result of the international idea in the late 1960s of promoting home ownership through housing co-operatives for low-income families.

With the support from International Housing Movement and the United Nations, in early 1970s, the government had managed to put in place a pilot project of Cooperative Housing in Mwenge, Dar es Salaam. The Mwenge Housing Cooperative was the pilot project that drew members from different sectors including public and private sector employees and self-employed Tanzanians. The lessons from Mwenge were replicated in other regions throughout the country. Thus, while in 1971 there were only 3 Housing cooperatives, this figure increased to 33 in 1987 and 117 in 1990 (Nnkya, 2000). By 1998, there were a total of 136 Housing Cooperatives. The total number of members to these Cooperatives also increased from 500 in 1971 to 6,257 in 1990 and to 6,613 in 1998 (ibid.). Most of these Cooperative Societies were Employee based.

It is important to highlight that even though the number of Housing Cooperatives showed a steady increase in the 1970s, the decades of 1980s and 1990s revealed a decreasing trend in both number of Cooperative Societies and members. This has been reported to have been caused by the introduction of market oriented economic reforms and the government withdrawal from being a central player in the provision of housing for the poor through Cooperatives. These changes together with dwindling economic performance of the country of the 1980s culminated into poor performance of many Cooperative Housing Projects and many of the vibrant Cooperatives of the 1970s have either ceased to operate or closed down.

Learning from the pilot project it was considered convenient to mobilize people (workers) under their employers in order to have employers' assistance in the management of resources especially funds that were to be borrowed from the Tanzania Housing Bank (THB). Other projects that followed later in the 1980s - 1990s were employer-based cooperative housing.

The Tanzania Housing Bank (THB) was established to facilitate housing cooperatives by providing loans. Following the collapse of THB in 1995 financing of the cooperative housing projects became difficulty. From late 1990s to date there have been isolated donor community-initiated cooperative housing projects with less government participation.

Following the economic reforms of the 1990s, the government reiterated its ambition to awaken the Cooperative spirit as a way of addressing housing needs for the poor. These efforts have been manifested in the establishment of the new Ministry of Cooperative Development and Marketing in 1995 and the Cooperative Development Policy of 1997 as was revised in 2002. This Policy accentuates the role of the government as to provide an enabling environment for new cooperative societies to be established within a competitive market oriented environment while ensuring that such societies are democratically established and have all the necessary conditions for their economic sustainability. The 2002 Policy statement underscores the need for cooperatives to be competitive when it is stated that:

'the policy puts emphasis on commercially oriented business minded leadership instead of civilservice oriented management in running the cooperative movement' (URT, 2002).

Consistent with these policy provisions, Part II section 5 of the Cooperative Act (2003) accentuates the duty of the government as to provide and to create conducive social, economic and legal environment for the development and prosperity of Cooperative Societies (URT,2003:11).

During the 1970s and 1980s, several housing units were constructed adopting prototype of house design which were in some Cooperatives part of the house construction package. Over the years, and with the drastic socio-economic reforms of the 1980s and 1990s, some of these houses have been transformed to suit new demands consistent with the prevailing socio-economic conditions. It is from these changing dynamics and policy reforms the study was formulated to carry out a comprehensive evaluation of these projects and analyse the current situation and challenges confronting cooperative societies. The main driving assumption here is that despite the seemingly failure of housing cooperative initiatives in the country, the same societies are still viewed as instrumental vehicles for facilitating the poor to access decent housing especially in the urban context.

According to ICA (1996) a co-operative is an autonomous association of persons united voluntarily to meet their common economic, social and or cultural needs and aspirations through a jointly owned 
and democratically controlled enterprise. The ILO defines cooperative as "an Association of persons who have voluntary joined together to achieve a common end through the formation of democratically controlled organization, making equitable contribution to the capital required and accepting a fare share of the risks and benefits of the undertaking in which the members actively participate (ILO, 1996). Since its creation in 1895, the International Co-operative Alliance (ICA) has been the final authority for defining co-operatives and for elaborating the principles upon which co-operatives should be based (ICA, 1996). At its Manchester Congress in September, 1995, ICA adopted a Statement on Co-operative Identity, which included a listing of the movement's key values, and a revised set of principles intended to guide co-operative organizations at the beginning of the twentyfirst century.The statement emphasizes that principles that form the heart of co-operatives are not independent of each other. They are subtly linked; when one is ignored, all are diminished. Cooperatives should not be judged exclusively on the basis of any one principle; rather, they should be evaluated on how well they adhere to the principles as an entirety. The Statement therefore provides seven principles to guide co-operative movements in the twenty-first century:

- Voluntary and Open Membership;

- Democratic Member Control;

- Member Economic Participation;

- Autonomy and Independence;

- Education, Training and Information;

- Co-operation among Co-operatives; and

- Concern for Community.

The first three principles essentially address the internal dynamics typical of any co-operative; the last four affect both the internal operation and the external relationships of co-operatives. The Statement emphasizes further more that co-operatives around the world must recognize more frequently the possibilities of more joint business ventures and they must enter into them in a practical manner, carefully protecting the interests of members. They must consider, much more often than they have done in the past, the possibilities of international joint activities (ibid.).

IHSS, (2002) notes that co-operatives are based on the principles of self-help, self-responsibility, democracy, equity and solidarity. In the tradition of their founders co-operative members believe in their ethical values of honesty, openness, social responsibility and caring for others. Co-operatives are guided by the principles of voluntary and open membership, democratic member control, member economic participation, autonomy and independence; education, training and information; cooperation among co-operatives and concern for community (IHSS, 2002).

Co-operative among individuals and family groups as a means of attaining common goals is as old as man and is in fact a basis of any organised society. Robert (1975) noted that the co-operative movements as it existed at that time had its beginning as late 1844. When 28 poor mill workers opened a shop in Rochdale England, stocked with small amount of butter, flour, oatmeal, sugar and candles purchased with funds pooled from their meager weekly savings (Robert, 1975). Robert further argues that one characteristic of a co-operative, which is sometimes misunderstood, is that, a co-operative is a genuinely voluntary, free-enterprise undertaking. Although most countries have been always regulating the formation and operation of co-operatives to protect the members, when a cooperative is dominated by the state or by any individual or organisation other than its own members, it ceases to be a true co-operative.

\section{Housing Cooperative Projects}

In Housing Cooperative Projects, households are enabled to pool resources to acquire and develop land and housing. They normally have access to finance that in many instances are driven from donors. Co-operatives also enable people to join forces and reduce costs in undertaking construction. Generally speaking co-operative housing projects are community owned and democratically controlled by its residents and operated for their benefit. The forms that housing co-operatives have taken in different countries have been influenced by indigenous customs, laws and socio-economic factors. Hence they vary from one country to another. However, those projects which follow the essential co-operatives principles are sometimes considered as co-operatives regardless of their legal structures and forms. 
Even though the specific objectives for establishment of co-operative housing may differ from one society to another, still the approach has its roots in the ever-increasing housing problems and related issues. In different circumstances the term co-operative housing may appear with different names but normally carrying the same meaning. In different countries this approach has been applied by governments or organised groups of residents to address specific housing issues of concern, in Scandinavian countries for example they have been called "communal housing" (Vestbro, 1992). The main concern however, has been to enable different groups of people to have access to housing and community life and other related services through their own participation and contribution in either house production or maintenance or both. According to Heyden (1981) the term "co-operative housekeeping" was introduced from the campaign against traditional homemaking and traditional housing where Melusina Fay Peirce, an angry housewife proposed that women unite to take control over their lives and work, which would also result into totally new approaches in urban design. Melusina considered housewives and daughters as economically and intellectually oppressed due to unpaid and unspecialised domestic work (unnatural sacrifice). Melusina (1869) wrote, co-operative housekeeping may be wholly practical or wholly visionary. But two things women must do somehow, as conditions not only of the future happiness, progress and elevation of their sex, but of its bare respectability and morality. First they must earn their own living and second they must be organised among themselves (Melusina, 1869, in Heyden 1981). In this case, co-operative housekeeping were formed by groups of twelve to fifty women who organised to form co-operative associations to perform all of their domestic work collectively and charge their husbands for these services.

While housing co-operative represents only a small part of co-operative movements and has been slower to develop in most countries than other forms of co-operatives, it has expanded dramatically since World War II. This is particularly true in North European countries and United States. It is now widely accepted as an important approach for housing middle and even some low-income families at a reasonable cost. It also offers a means of improving the quality of community life through the provision of a variety of community services owned, operated or sponsored by the co-operative societies and their members (Robert, 1975; Vestbro, 1992).

\section{TYPES OF HOUSING COOPERATIVES}

According to IHSS (2002) housing co-operatives can generally be grouped under four main categories. These are Limited Objective, Mutual Ownership, Multiple Mortgage and Tenant Cooperatives.

\section{"Limited Objective" Co-Operative}

These are formed to undertake certain specific services on behalf of the members. Often they involve only acquiring and subdividing land with title to the lots given to the individual members. In some cases the co-operative may go further and arrange for the installation of streets and utilities and even the design and construction of the dwellings. However, once the objectives of the members have been met the co-operative usually dissolves.

\section{"Mutual Ownership" Co-Operatives}

These are sometimes referred to as "single mortgage" co-operatives. In this type the co-operatives may perform all the activities described above but in addition retains title to the land, dwellings and facilities. In this case the co-operative, which is mutually owned by the members, manages and maintains the property on behalf of the members after it has been completed. Sometimes it may be formed to acquire a housing project already in existence. Example in U.S, the Greenbelt co-operative was formed to acquire the planned community of Greenbelt Maryland, which had previously built and owned by the U.S Government (IHSS, 2002). In this form of co-operative the legal title to the entire property including the dwelling, land and facilities is held by the co-operative society. However the members are the actual owners by virtue of the fact that they own all the shares in the co-operative. Each member's shares are equal to the value of his particular dwelling unit and his proportionate share of the common property. The members occupy their dwelling units under what is commonly known as an 'occupancy agreement'. In the United States this is usually in the form of a 'lease' for a term of years, which is automatically renewable.

\section{"Multiple-Mortgage" Co-Operatives}

This type is mainly found in Latin American countries and in Israel. They are a form of condominium or "horizontal property". Members hold legal title to their individual apartments or dwelling units but with all common property and facilities owned by the owners of the dwelling units (ibid.). 


\section{Tenant Co-Operatives}

Found mostly in Europe particularly in France and some Eastern European countries. A non-profit cooperative builds dwellings and leases them to its members. The occupants do not have equity or own any share in the property but do have a voice in its day-to-day management. There are also cooperatives, which are developed and managed by builders or real estate interests for personal profit. Such projects may have many of the outward trappings of a true co-operative, but they usually violate the basic co-operative principles in one or more ways (IHSS, 2002).

\section{Methodology}

Case study research strategy was used. The two urban centres that were selected for detailed study were Dodoma and Dar es Salaam. Dar es Salaam is the largest city in Tanzania with a fairly long history of co-operative housing projects. Because of the underlying socio-economic and historical factors, it attracts more people and therefore is constantly under pressure for demand of low-cost housing. Dar es Salaam, therefore, represents an interesting case with challenging exposition of the study phenomena

There were four key methods employed in data collection. These included: review of relevant documents, interviews, observations, measurements and photographic registration.

Social economic data was collected through household interviews using open ended and structured questionnaires. There were a total of 202 households that were interviewed. These included 53 households from Mapinduzi Housing Cooperative, 50 households from Nala Makazi, 50 households from Mwenge Housing Cooperative and 49 households from Sigara, Sinza Housing Cooperative. The first two Cooperative Projects are in Dodoma while the latter are within Dar es Salaam City. Heads and representative of household heads were asked to unveil their socio-economic data and status, occupancy characteristics, housing condition, availability and condition of community facilities, community organisations, Home Based Enterprises (HBEs), safety and security of their neighbourhood, infrastructure services and their evaluation on the quality of buildings and settlement. Enquiry on establishment of the cooperative, design of buildings, financing and building ownership was also sought from household interviews. In these interviews, the nature of the data collected was both qualitative and quantitative as well. The qualitative data qualified further the quantitative information collected.

\section{RESULTS AND DISCUSSION}

This section pools together the key observations emerging from the four case study Housing Cooperative Areas. These observations are reflected upon policy frameworks that are directly related to housing cooperatives development in Tanzania. Further, it highlights on the challenges and potential qualities of housing cooperative societies as vehicles for facilitating their member's access to decent housing.

\section{The impact of changes in macroeconomic policies on the development of housing cooperatives}

One of key variables that have played a significant contribution towards the decline of housing comparative movement in Tanzania is the shift in focus of macro-economic policies from centrally planned socialist to market-oriented economic policies. Since independence, Tanzania has gone through three distinct phases of macro economic changes. These include; the first phase of government (1961-1984) under the leadership of President Julius Kambarage Nyerere. Under this phase the main economic focus and impetus were on investment for rapid modernization, equitable social development under the social welfare paradigm (Ngware et al, 2003). The socialistic ideals as stipulated in the Arusha Declaration $(1967)^{1}$ became the hinge points of macro-economic policies from 1967 to early 1980s. Economic policies were characterized by controlled investment and centralization of factors of production by the government with limited private sector involvement in the country's economy. It was during this phase that cooperative movement and societies were highly supported including the Housing Cooperative Societies. Housing Cooperatives advocated collective ownership of properties and were therefore consistent with the Ujamaa policies.

\footnotetext{
1 The 1967 Arusha Declaration established the principles of Ujamaa Policy in which the main factors of production were put under the control of the government. The Declaration laid down the key principles of socialism and the country vision. It draws its name from Arusha because the declaration was made in Arusha by the then Ruling party of Tanganyika African National Union, TANU.
} 
It was also during this period that a pilot project for Housing Cooperative was initiated at Mwenge with substantial technical support from public institutions such as the National Housing Cooperation (NHC) who built the Houses to foundation level and the Tanzania Housing Bank (THB) that provided financial loan to cooperative members to finalise construction of the houses. Further, it was during this phase that many housing cooperatives were established increasing from 3 in 1971 to 33 in 1987. The motivating factors for such establishments included the availability of loans from public housing financing institution, the Tanzania Housing Bank (THB) and the urge by the government for employers to support their employees particularly the low-income to establish employer-based Housing Cooperative Societies.

Despite the achievements under the social welfare government, this policy orientation could not be sustained because of weak economic growth. It was in early 1980s that the country economic situation started to decline. For example, the respective year minimum monthly wage at constant 1970 values decreased from 220 in 1973 to 40 in 1993. This is equivalent to 82\% decline in real values (URT, 1995). While wage values were decreasing significantly, public sector employment increased from 104,546 in 1961 to 462,160 in 1984. Proportionately, this represented an increase from $26 \%$ to $73 \%$ of total wage employees in both public and private sector. Private sector employment shrinked from 297,300 (74\%) to 171,220 (27\%) over the same period (1961-1984) (URT, 1995). This indicates clearly the legacy of the first phase government on public sector and social welfare even though economic performance was dwindling. For example the growth in GDP decreased from $14.5 \%$ in 1966 to $3.0 \%$ in 1983 (URT, 1995).

The second phase 1985-1995 dismantled the controls and introduced liberal and market oriented economic system. This system was characterized by changes in the pricing system, reduction on controls for imported goods, and participation of the private sector in the economy. However, it left the foundation of the orderly market system unattended (Ngware et al., 2003). Despite liberalisation of the country's economy, including macro economic reforms through for example the Structural Adjustment Programmes (SAP), living condition for the majority of the urban poor continued to deteriorate. For example, the 1990-91 labour force study estimated that there were 8.9 million people aged between 15 and 64 years who were economically active, about $10.7 \%$ of urban were unemployed. While by 1992 , about 700,000 people were entering the labour market, only 30,000 got employment in the formal sector (Kombe, 1999). This period of economic reform witnessed a decline in formal employment and burgeoning of the informal sector. It is estimated that the informal employment sector has a capacity to employ about $62.5 \%$ of the annual increase in labour force while the formal sector can absorb only 8.5\% (Kombe 1999). Typical experiences from these reforms included for example a massive retrenchment of government employees from early 1990s to 1999. Between 1993 and 1996 for example, a total of 61,000 workers were retrenched from the government sector (Wangwe and Tsikata in Kombe 1999).

Since the majority of the Housing Cooperatives were employer-based retrenchment of government and parastatal organizations' employees contributed immensely to the collapse of these societies. In Sinza urban centre in Tanzania for example, all 80 members of the Sigara Housing Cooperative society were retrenched from employment by 1995 . Even though these cooperative members had accomplished their houses by the time of their retrenchment, it adversely affected those under phase III of the project who could not secure even financial loan from THB. It was also during this period that the performance of TBH dwindled leading to its closure in 1995. This was compounded by the fact that it could not compete under the liberalized economic environment. This marked the end of formal housing financing system in the country with adverse effect to Housing Cooperative Societies. Hamzah (2015), states that escalating housing prices has led into higher house prices. This means majority of people will not afford access to decent housing.

The third phase of the government 1995-2005 focused on sustaining macro-economic stability, restoring fiscal disciplines and creating an institutional base for supporting market economy and greater participation of the private sector. These policy dynamics contributed to a considerable change in the country's economy in a number of ways. The real growth in GDP rose from 1.7\% in 1992 to 4.9 in the year 2000 and the average for the whole period was $4.1 \%$. Real growth in the agricultural sector rose from $1.2 \%$ in 1992 to $3.5 \%$ in 2000 . The diminishing trends in the manufacturing sector have been reversed from $0.2 \%$ and $1.6 \%$ in the years 1993 and 1994 to $4.8 \%$ in 2000 and an average of $4.6 \%$ between 1992 and 2000. Domestic savings of GDP reversed from -2.4\% in 1992 to 5.6\% in 
the year 2000. During the same period the rate of inflation was reduced from $21.8 \%$ to $5.5 \%$ (Ngware et al, 2003). While in the previous phases the issue of scarcity of building materials necessitated some of the housing cooperatives to order these materials from the factories, in the later phases building materials were flooded in the market but the problem has been that the poor cooperative members have no capacity to purchase because of lack of finance.

Despite the economic strides, the situation in most of Housing Cooperative Societies has continued to worsen apparently because most of the old societies are yet to adapt to the changed economic environment apart from the fact that majority of the members in the old societies consider to have achieved their goals, namely; the houses. In responses to the collapse of a Government Housing Financing Institution (THB), many cooperative societies that managed to survive have started to establish new sources of financing of their cooperative activities. The most common facility has been the Savings and Credits Cooperative Societies (SACCOs) as observed in Nala Makazi Housing Cooperative Case. Country wide, and across all forms of cooperatives, SACCOS have increased from 1,084 in 2002 to 1,268 in 2003 and further to 1,609 in 2004. Members also increased from 142,700 to 163,700 and further to 273,378 within the same period (URT, 2004). This indicates how low income people are struggling to solicit alternative sources of finance, following the collapse of the formal housing financing institution.

Even though Housing Cooperatives were not the major contributors in the housing stock in urban areas countrywide, they played a significant role in some parts of Tanzania especially in Dar es Salaam and Dodoma. The collapse of the Housing Financing system affected not only the Housing Cooperatives but also private developers who contribute towards the whole question of estates development. The Economic Survey Report (2004) for example shows that the contribution of Real Estate Development to the overall GDP of the country slightly increased from $9.8 \%$ in 1994 to $10.8 \%$ in 2004 at factor cost and from $2.4 \%$ in 1994 to $2.7 \%$ at monetary and non-monetary values. Owner occupied dwellings contribution rose from $7.4 \%$ to $8.1 \%$ from 1994 to 2004 (URT, 2004). It is imperative from these trends that real estate contribution to the overall GDP has almost stagnated over the past decades. The key factor for this stagnating situation is to some extent related to changes on macro economic policies that apart from being unfavourable to the poor, are not favouring group efforts initiated under the Housing Cooperative Societies.

\section{Housing Cooperatives as Vehicles for Households' Access to Decent HOUSING}

One of the key observations from study areas is perhaps the type of cooperative societies that were developed in 1970s. They were largely the Limited Objective Cooperatives whereby members had targeted houses for owner occupation as their main objective. The Mwenge Housing Cooperative was a Mutual Ownership whereby communal ownership to land was the form of land tenure. However, over time, members are processing to acquire individual tittles to land. These new trends are a result of changes in the macro-economic policies of the country but also a sign of liberal economic policies precipitated by the on-going re-orientation and emphasis from communal to private ownership spirit.

Nnkya (2001) observed that the number of housing cooperative members grew from 500 in 1971 to 6,613 in 1998. If this number corresponds to the total number of houses, then Housing Cooperatives would have significantly contributed towards shelter provision to the poor. However, since not all members secured housing loans from THB, nor has there been a study to take inventory of houses constructed by cooperative societies, the contribution in housing stock country wide is yet to be known.

As vehicles for households' access to decent housing, it is notable from the four case study areas that Housing Cooperatives has played a significant role in many ways. First is the fact that most of the low income households have been facilitated to acquire plots namely 122 plots for Mapinduzi, 100 for Nala Makazi, 2002 for Sigara and 395 for Mwenge. The plots were availed to cooperative members amidst scarcity of surveyed plots in the 1980s. It would have been difficult for individual members to pursue plot acquisition processes. Second is house construction. Cooperative members were facilitated to build their residential houses using permanent building materials even though in some projects houses were constructed on incremental basis. Third is the technical support provided to the cooperative societies. This ranged from acquisition of house design, professional advice on house construction including construction materials and phasing of house construction. The technical advice 
that was provided either free or at subsidized price contributed towards reducing construction costs. The forth aspect is financing. Housing Cooperatives that were established in 1970s and 1980s managed to access financial loans from the then Tanzania Housing Bank (THB) for their members. This component was crucial in house construction apart from the fact that in some instances, the amount of loans was not adequate for cooperative members to complete their house construction.

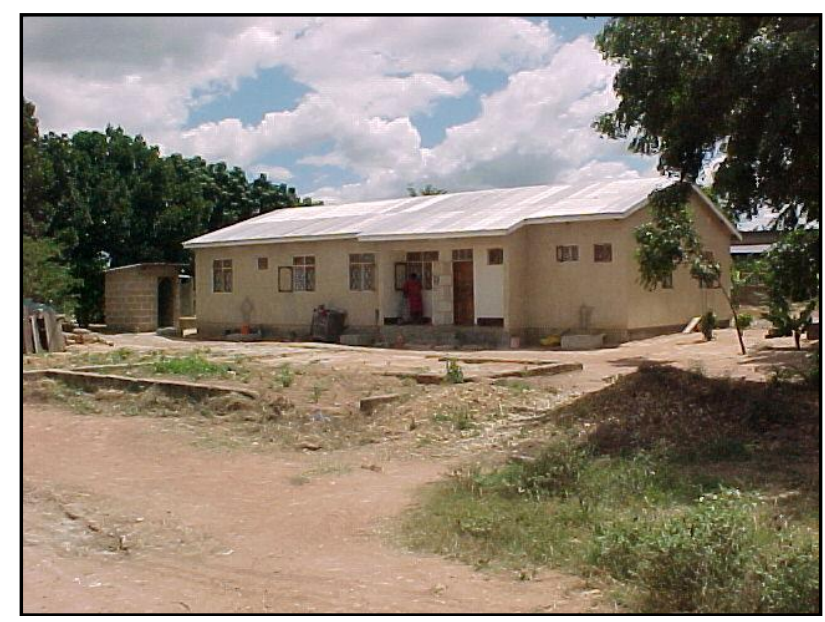

Fig1. A house constructed through cooperative efforts in Dodoma, Tanzania.

Even though non-cooperative members were also accessing loans from THB, it was relatively easy for individuals who had joined hands through a Housing Cooperatives Society to access such loans. This is also applicable even to recently established Housing Cooperatives such as Nala Makazi whereby resource mobilization has been made possible by pooling together scattered individual efforts. Although the pace of development in the later society is low, they present an upcoming force to reckon with when it comes to sustainable resource mobilization for house construction.

The fifth aspect is access to building materials. Due to poor economic performance in the 1980s, building materials were severely scarce creating more difficulties in terms of house construction. Through Housing Cooperatives members were facilitated to purchase materials in bulk directly from the factories. This endeavor not only facilitated acquisition of materials but also purchased at a relatively lower price contributing to lowering construction costs.

The sixth aspect is acquisition of long term titles by individual members. In Housing Cooperative Society areas such as Mwenge the title to land was a collective one. Over the years individual members have started processing titles to land and properties. Impliedly they will be having documents necessarily for mortgages and be used as collateral to access loans in the liberalized economic environment. Out of 50 houses in Mwenge for example, 19 owners had already attained long term title to land as of June 2004.

Seven is the whole aspect of skills development. Through the Housing Cooperatives, leaders and other members were trained and imparted skills related to construction materials, building technology, alternative building materials such as stabilized sand cement blocks and management and operations of SACCOS. These skills contributed significantly in facilitating access to decent housing.

Eight is access to community facilities and infrastructure services. Across the four housing cooperative societies, there were provision for water, electricity and paved or surfaced roads. The Mwenge case for example, is one of the few residential areas in Dar es Salaam that is served with a sewerage system. Even in recently established cooperative such as Nala Makazi, it has been possible to access water through financial support from WAT. Hence, apart from constructing basic shelters in their respective areas, housing cooperative has assisted their members to have access to these basic services.

Nine is the whole question of self-help spirit and mutual self help which has been the key component in Nala Makazi. The fact that the Nala Makazi members are constructing houses without support from financing institutions, mutual self-help has played a significant role in whatever success that has been recorded from this society. Attendance during self-help in this society was reported to be high essentially because members have managed to develop the spirit of commitment towards mutual selfhelp and being responsible for their agreements. 


\section{INNOVATIVE RESOURCE MOBILISATION AND HOUSING FINANCING MECHANISMS}

While most of the Housing Cooperatives that evolved in the 1970s and 1980s had at least a financial support from THB and partly from their employers, cooperative societies that emerged later face more challenges in term mobilizing financial resources to fund house construction. Typical of such a society is the Nala Makazi. These challenges are mainly caused by the changes in the macroeconomic policies whereby cooperative spirit and social welfare towards the housing sector have not been given due consideration. Important lessons, however, that emerge from Nala Makazi is the way the society has managed to establish innovative approaches in mobilizing housing finance. The society introduced registration fees and monthly contribution as was in other societies. It has also introduced the Rotating Savings and Credit Associations (RoSCAs) and established a SACCOs in which shares are being sold to enable members access relatively larger loan amount to fund construction of their houses. By establishing a SACCOs, they have opened a window to access Bank loans that can assist members directly borrow funds from commercial banks. These innovative initiatives are worth emulating especially to recently established cooperatives if they are to survive in the changed macro economic policy of the country.

\section{Realisation in Project ObJectives and Housing as Assets}

There have been substantial achievements in objectives and realization of housing as assets by the cooperative members. Evaluating achievement in objectives across the four case study areas, it is notable that substantial strides were made despite the drawbacks experienced in the process of implementing the projects. For example, all the four case study cooperative societies registered considerable achievement in terms of plot acquisition and house construction namely in Sigara (100\%) and Mwenge (100\%), soliciting loans and resource mobilisation successful in Mapinduzi $(100 \%)$ and Nala Makazi (80\%). These achievements enabled low income households to access decent housing which could have been difficult if it was done on individual basis. Housing as assets have assisted cooperative members not only as basic assets for habitation but also for income generation through renting. Renting of houses as a source of household income was very common in Mwenge, Sinza and Mapinduzi housing cooperative areas. Over a period of time house owners have extended their houses to accommodate addition rooms for renting or home based enterprises.

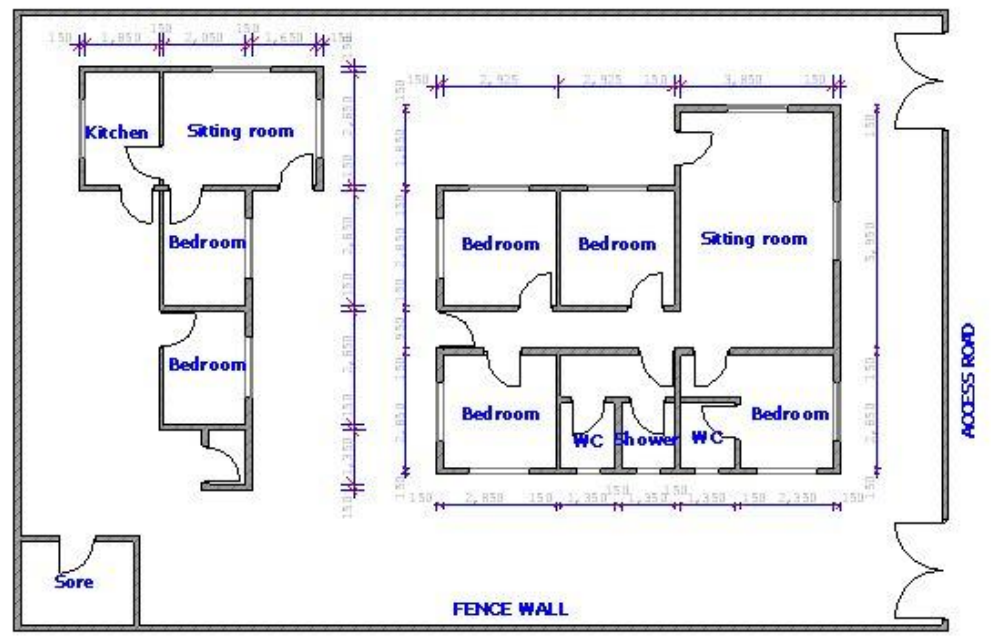

Fig2. An example of cooperative house where extension took place by providing another small structure on the same plot. The original house is the one on the right side. The left side house was added later. It is rented out to another family

The fact that the majority house owners in Sinza, Mwenge and Mapinduzi Housing Cooperative areas have been retrenched from employment, they have found employment in the informal sector but house renting has constituted one of their other sources of income.

\section{Weak Institutional Arrangement to Promote Housing Cooperatives}

Apart from the impacts of the changing economic environment, the weak institutional arrangement precipitates the poor operating environment of housing cooperative societies. Although the Cooperative Union of Tanzania (CUT) has been regarded as the apex of all cooperative societies, 
housing has not constituted a substantive agenda in this union. CUT has focused more on agricultural societies and marketing of agricultural produce. It is not surprising that Housing Cooperatives are not mentioned in both the Cooperative Societies Act (2003) and the Cooperative Development Policy (2002). Unlike in Kenya where the National Cooperative Housing Union (NACHU) forms the apex institution of primary and secondary societies, in Tanzania such an institution is non-existent. Therefore, it has been difficult for Housing Cooperatives to coordinate activities done by various housing cooperatives by way of sharing experience and in terms of networking. Apart from the lack of an apex organisation, the organizational structure stipulated in the Act provides limitations for Housing Cooperative Societies to diversify activities and address contemporary needs as circumstances change. For example section 4.4.2 of the Act (2003) stipulates that the general meeting shall be the highest organ under which shall be located a Committee or Board and further a Manager. This limitation in terms of committee to be formed by the society does not give room for flexibility for the society to establish pertinent committees that can enhance the functioning of the society. The Nala Makazi for example established several other committees such as the Finance, construction, water, disciplinary, environment and HIV/AIDS all of which constitute the current agenda to be addressed by the cooperative societies.

Another issue emerging from institutional and organisational arrangement is related to leadership. In some cooperative societies where the government was in the forefront in their establishment there have been complaints from the cooperative members for the overstay of the leaders beyond the period prescribed in their constitutions. The fact that cooperative sprit has almost ceased in these societies, some leaders have remained as 'de-facto' office bearers with minimal support from members. The situation is further complicated for retrenched employees who remain as neighbours in the areas but without a binding element that brought them together, that is, the employer. In Sigara cooperative members were considering changing their constitution so as to take into account the change of employment status of its members. Important also under institutional arrangement is the shifting nature of the Department responsible for the promotion of cooperative activities in the Ministry responsible for Cooperative development. While at certain period of time the cooperative Department was under the Prime Minister's Office, in 1995, a full-fledged Ministry of Cooperative Development and Marketing was reconstituted. However, in the reconstitution of new Ministries under the $4^{\text {th }}$ phase government (2005), this Ministry has been dissolved and the Cooperative Department has been shifted to the new Ministry of Agriculture Food Security and Cooperatives. It is apparent from this set-up that much of the cooperative ideas are essentially agricultural-sector centered with limited focus to other forms of cooperatives such as housing. The continuous shifting of the department not only affects its orientation to other Ministries but also affects the long term plans prepared under a specific ministry.

\section{Policy Implications}

Policy implications discussed below are geared towards analyzing how relevant policies promote Housing Cooperatives as essential vehicles for poor households' access to decent housing. Policies discussed include the cooperative development policy (2002), Poverty Eradication Strategy (1998), the Nation Development Vision (2025) and the Human Settlement Development Policy (2000).

\section{Housing Cooperatives in the Context of Cooperative Development Policy (2002)}

The Cooperative Development Policy (2002) highlights the main constraints facing cooperative development in the country as; inability of the cooperatives to operate under liberalised economy due to weak structural and financial positions, weak institutional management, misappropriation of resources and political intervention (URT, 2002: 2-3). Therefore, the present situation on the level of operations of most housing cooperatives is largely associated with these major factors. The Cooperative Development Policy envisions having a cooperative system that is geared towards improved and sustainable cooperatives that are capable of fulfilling members' economic and social needs (ibid). Section 2.4 of the Policy identifies the bias on marketing and agricultural sectors with little emphasis to other sectors housing being one of them. In view of this weakness, the policy provides for the government to encourage establishment of cooperatives in other sectors. Similarly, section 4.0 provides for structural framework of the cooperative movement. The policy statement emphasises on the autonomy of primary societies to establishing flexible horizontal and vertical structures that ore economically viable. 
While this suggestion sounds to targeting a bottom - up approach, one of the challenges in achieving this pattern is on how to develop strong grassroots cooperatives and the fact that such primary societies have in many cases received little support from the government. It would further be difficult for primary cooperative societies to solicit funding from outside the country unless deliberate efforts are made to develop both capacity and institutional structures that can be recognised by both financial institutions and donors.

Most of the housing cooperative societies that flourished in the 1970s and 1980s namely; the Mwenge, Sinza and Mapinduzi have almost collapsed due to limited institutional support to facilitate such societies to keep moving. However, the created community assets are there and are effectively being used by cooperative members. The Nala Makazi, a housing cooperative that emerged in the 1990 s within the liberalised economic environment has not been adequately supported to act as a catalyst for low-income households' access to decent housing and contribute effectively in addressing the national vision and the poverty eradication strategy despite its exemplary and innovative approach towards resource mobilisation and sustainability.

\section{Housing Cooperatives in the Context of the Tanzania Development Vision 2025}

The five basic issues that have been enunciated in the Tanzania Development vision (2025) include high quality livelihood; peace, stability and unity; good governance; a well educated and learning society and competitive economy capable of producing sustainable growth and shared benefits (URT, 1999:2-3). Of direct relation with Housing Cooperative Projects is the quality of livelihood. Under this issue, the national vision is to achieve people - centred development based on sustainable and shared growth that is free from abject poverty. This vision focuses on creating wealth and its distribution among the society in which racial and gender imbalances are addressed. Emerging from the four Housing Cooperative Societies is essentially an asset building process (housing) that is centred on the people - the cooperative members. A 50-50 men and women membership pattern in Nala Makazi is a clear manifestation that this cooperative society is non-gender biased and attempts to redress gender imbalances that has prevailed in other sectors for a long time. Where women are empowered in equal terms as men is a success story that policy makers and development agents will need to emulate in other developmental projects and programmes. Nala Makazi is such an example that has shown the way and there are a lot more to learn from this Housing Cooperative Society. On the issue of education and learning society, the vision endeavours to build a nation whose people have positive mindset and culture of hard work, entrepreneurship, innovativeness and creativity, community spirit that is balanced with individual initiative (URT, 1999:5). Despite the fact that not much in terms of physical development has been achieved in Nala Makazi, the establishment, operations and community spirits and innovations that have been developed by this Housing Cooperative are worth emulating in other communities. The establishment of local financing mechanisms and resource mobilisation by the Nala Makazi is quite consistent with this vision. The challenge to the government is how such initiatives and innovations can be supported to realise a wide-embracing coverage as a strategy to achieving the vision.

\section{Housing Cooperatives in the Context of the National Poverty Reduction Strategy (1998)}

One of the indicators of poverty as highlighted in the National Poverty Reduction Strategy (1998) is poor quality houses. It has been stated that while by 1995 about $70 \%$ of the population in Dar es Salaam lived in squatter settlements, the same rate (70\%) applied for Arusha and Mbeya municipalities. Pertinent to the causes of poverty that relates to cooperative societies, this paper indicates that erosion of democratic institutions and marginalisation of people such as local councils and cooperatives denied the participation of the people in the management of the economy and their contribution to development activities (URT, 1998). Emily P, at al (2014) contends that, income and services impede families access to decent, safe and affordable housing. In addressing the issue of decent housing for all as one of the strategies for poverty eradication, the government underscores the need to support people's initiatives to establish and strengthen local cooperatives..

Despite these renewed strategies, presently very little is being done to en-liven the collapsed Housing Cooperatives of the 1970s and 1980s. Housing as an important component of the cooperative movement and restructuring does not seem to emerge prominently from this end. Emphasis has for many years centred on agricultural and marketing cooperatives. To date, there is no umbrella organ that coordinates housing cooperatives at city and town levels. In Kenya for example, the National Cooperative Housing Union (NACHU) was established in 1978 as an apex organisation that unites the 
Kenyan Primary Housing Cooperatives (UNHS, 2003:11). The need for establishing an apex housing cooperative is therefore calling as a strategy towards operationalising recommendations raised in the poverty eradication strategy paper. However, the establishment of such a society ought to be bottomup, free from government influence and should not constitute a burden to secondary and primary societies in terms of operations as stipulated in the Cooperative Development Policy (2002).

\section{Housing Cooperatives in the Human Settlements Development Policy (2000)}

Human Settlement Development policy recognizes the role played and potentials inherent in housing cooperatives and other organized groups. This policy further acknowledge the diminishing trend in terms of housing cooperatives contributions in the provision of decent housing to low income earners. Further, the policy cites the causes to this trend as the lack of clear policy on how housing cooperatives should operate and lack of implementation structure which could ensure accountability. Another obstacle has been cited as the centralization of the cooperative movement. In order to address these issues, the policy provides for the following statements.

- Promote, support, and encourage the development of housing through cooperatives, CBOs, NGOs, and building societies.

- Initiate research to establish reasons for the poor performance of organized groups in housing production with a view to find out how best to support and assist those groups.

- Review the institutional set-up for preventing cooperative housing so as to involve more the cooperative unions and local authorities. Besides, these statements, the policy further provides for the strategies to facilitate realization of these statements. Some of these strategies included; encouraging formation of CBOs, NGOs in areas where people have already shown interest of developing their housing, educate people of building technologies, government to make building plots available, make housing credit facilities available and training in elementary book keeping and administration (URT, 2000).

While it is notable that the government partly played its role in such aspects as making plots available, to the large extent it has not lived to the expectation of these policy statements and strategies. It is more than ten years since when the only housing financing institution collapsed (THB) in 1995. Virtually there have been no efforts to establish alternative housing financing institution to date. While the Nala Makazi has been struggling to solicit housing finance from their own means, there has been little support from the government to spearhead these initiatives apart from allocation of unserviced plots to the members. Members under phase III of Sigara Housing Cooperative were not successful in acquiring surveyed plots. They were compelled to mobilise own resources to pay for the compensation and survey costs in Yombo Vituka area in Dar es Salaam. Infrastructure services were not provided. These examples show that the government is yet to play its role and input required to support housing cooperatives as stipulated in this policy. Compounded with the macro-economic changes and the limited governments' role in the housing cooperative projects, members in these societies continue to navigate through with many difficulties. There is therefore a need for the government to specifically and clearly state as to how these policy statements can be operationalised by for example developing programmes to support grassroot housing projects.

\section{CONCLUSION}

This paper has shown that Housing Cooperatives Societies are potential vehicles for low income households to access decent housing. In the 1970s and 1980s these societies flourished because they enjoyed a considerable government and policy support. Housing cooperative societies were facilitated in terms of acquisition of surveyed plots, access to housing finance (loans), basic infrastructure and community facilities provisions, acquisition of building materials and technical advice from government and parastatal organizations. Most of these Societies were employer-based. Considerable achievements were made in the decades of 1970's and 1980s. These achievements included the increase in number of housing cooperatives and therefore households access to decent housing, increase in number of houses built and basic community facilities and infrastructure services in respective housing cooperative areas. It is estimated that more than 906 units were constructed by these housing cooperative societies in late 1980s. However, changes in the macro-economic policies from the socialist welfare state to market-led and private sector driven economy has resulted into a 
competitive environment in which public sector institutions that could not withstand competition to collapse. One of these institutions was the Tanzania Housing Bank (THB) that played a key role as the main housing financing institution. Changes in the macro-economic policies also culminated into massive retrenchment of government and parastatal organizations employees. Since many of the Housing cooperative Societies were employer based, retrenchment from employment resulted into the collapse of many housing cooperatives.

Housing Cooperatives that have been or being established after the 1990s are confronted with a number of challenges some which include difficulties in soliciting sustainable ways for resources mobilization including finance, limited government support in terms of policies and legislative arrangements unsecured employment and income as majority members are working in the informal sector and lack of apex organisations to coordinate initiatives from primary and secondary societies including networking. As revealed from Nala Makazi, despite the innovative approaches in resource mobilization namely; Registration fees, monthly contributions, Rotating Savings and Credit Associations (RoSCAs), establishment of a Savings and Credit Society (SACCOs) and mutual selfhelp, the fund mobilized so far is inadequate to construct many houses for the cooperative members. The pace of house construction is rather slow and is being done on incremental basis. Amidst this challenging exposition, the Nala Makazi is one of the cases that have shown the way on how other Housing Cooperative Societies comprising low-income households can slowly develop mechanisms towards incremental house construction within the liberalized economic environment.

There is an ambivalent situation when policy environment and implication with respect to Housing Cooperatives is brought into discussion. While the government has repeatedly reiterated its ambition to facilitate and provide an enabling environment to cooperative societies, limited initiatives have been forthcoming especially to housing cooperatives. Understandably, while a number of initiatives have been done in other cooperative sectors such as agriculture and marketing, corresponding efforts have not paralleled the housing question. Almost all policies namely the Cooperative Development Policy (2002), the Tanzania Development Vision 2025 of 1999, National Poverty Reduction Strategy 1998 and the Human Settlement Development Policy of 2000) provide statements that encapsulate housing and housing cooperatives as key variables for improved living and livelihood and as vehicles for the poor to access decent housing. However, these policy statements are yet to be translated into programmes and projects and therefore provide an impact to the poor towards improved living environment.

It is imperative that there is a need to maintain a viable cooperative housing movement as a model of housing production. The government and other stakeholders should promote and support the question of bringing together the existing housing cooperatives to join together, establish an umbrella-housing cooperative that will coordinate the operations of the housing cooperatives in Tanzania including the question of networking. The functions and operations of such an umbrella organisation should not be limited to networking alone but also facilitate primary and secondary housing cooperative societies in terms of capacity building in the aspects of management, legal, documentation, training and coordination. The apex organisation should support these societies by soliciting alternative financing sources for affordable housing through networking and also to facilitate sharing of experience on matters related to management of cooperatives consistent with the changing economic environment.

\section{REFERENCES}

Emily P, Wilson R. and Logan J. (2014). Nowhere else to go: Inadequate Housing and Risk of Homelessness among families in Toronto Aging Rental Buildings, Published in the journal of Cities Centre, University of Toronto, Vol III, pp 39.

Hamzah, H., ( 2015): Housing cooperatives as an alternative house for Malaysian Gen Y .Conference paper of Pacific Realm Real Estate Society presented in a conference, 2015 at Kuala Lumpur

Heyden D., (1981), The Grand Domestic Revolution: A History of Feminist Designs for American Homes, Neighbourhood and Cities, The Massachusetts Institute of Technology, England.

IHSS, (2002), Tanzania Housing Profile: Towards a National Housing Programme, Draft Report Compilation of Papers Presented in a Consultative Workshop on a National Housing Program (NHP) on $26^{\text {th }}$ February 2002. 
International Labour Organisation, (1996), Cooperative in Developing Countries, Recommendations, Geneva, Switzerland.

Institute of Housing and Urban Development Studies , (1993), A Reader in Housing Renewal and Urban Heritage, IHS, Rotterdam.

International Cooperative Alliance, (1996), Background Paper to the Statement on the Co-operative Identity, 8 January 1996.

International Cooperative Alliance-UNCHS-Habitat, (2001), Shelter Cooperatives in Eastern and Southern Africa, ICA, Nairobi.

Johansson R., (2002), Evaluation in Case Studies, Royal Institute of Technology, KTH, Stockholm.

Kamau R, (1985), Co-operative Housing Development in Kenya: A Socio-Economic Appraisal, Housing Research and Development Unit (HRDU), Nairobi.

Kombe W, (1999), Urban Poverty, Service Provision and Land Development in Tanzania, Tanzania Institute of Engineers, Arusha, Tanzania.

Kvale S., (1996), InterViews; An Introduction to Qualitative Research Interviewing, SAGE Publications, California.

Larsson A., (1988), From Outdoor to Indoor Living; The Transition from Traditional to Modern LowCost Housing in Botswana, Lund University, Lund, Sweden.

E.J.A and Gashumba C.H., (Eds.), Promotion of Housing Co-operatives in Tanzania, Seminar Proceedings, Centre for Housing Studies, Ardhi Institute, Dar es Salaam, pp. 41-45.

Ngware S, Kironde J, Manda P, Malya U, (2003), Local Government in Tanzania; A Country Profile, Association of Local Authorities (ALAT) Report, Dar es Salaam, Tanzania.

Nnkya T., (2000), The Contributions of Cooperatives to Shelter Development in Tanzania, Final Report, Dar es Salaam, Tanzania.

Nnkya T., (2001), Shelter Co-operatives in Tanzania, Habitat and ICA, Nairobi.

Robert J. D., (1975), Co-operative Housing, A Revision of Co-operative Housing in the United States: Ideas and Methods, Exchange No. 52, Office of International Affairs, Department of Housing and Urban Development, Washington, D.C. 20410.

Turner F., (1967), Barriers and Channels for Housing Development in Modernising Countries, In Journal of American Institute of Planners, No. 3, Volume 33.

Turner F., (1968), The Squatter Settlement; An Architecture that Works, in A.D., Vol. 38, No. 8.

UNCHS-Habitat/ICA, (2001), Shelter Cooperative in Eastern and Southern Africa, Nairobi, Kenya.

URT, (1991), The Cooperative Societies Act, No 15, Government Printers, Dar es Salaam, Tanzania.

URT, (1995), Statistical Abstract: 1995, Bureau of Statistics, Presidents Office, Planning Commission, Dar es Salaam, Tanzania.

URT, (1998), The National Poverty Eradication Strategy, Vice President's Office; Government Printers, Dar es Salaam, Tanzania.

URT, (1999), The Tanzania Development Vision 2025, The President's Office; Planning Commission, Dar es Salaam, Tanzania.

URT, (2000), The National Human Settlements Development Policy, Government Printers, Dar es Salaam, Tanzania.

URT, (2002), The National Cooperative Development Policy, Government Printers, Dar es Salaam, Tanzania.

URT, (2003), The Cooperative Societies Act, No. 20, Government Printers, Dar es Salaam, Tanzania.

URT, (2004), The Economic Survey, The President's Office-Planning and Privatisation, Dar es Salaam, Tanzania.

Vestbro D., (1992), The Study of Collective Housing; A Swedish Perspective, in Arias E., (eds.), The Meaning and Use of Housing; International Perspectives, Approaches and their Implications, Avebury, pp 405-424. 


\section{AUTHOR'S BIOGRAPHY}

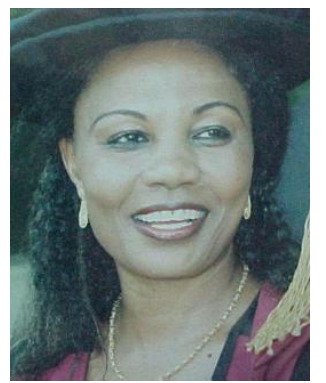

Dr. Huba Nguluma, is an Architect and Senior Research Fellow at the Institute of Human Settlements Studies of the Ardhi University, Dares Salaam, Tanzania. She was trained as an Architect and employed by Ardhi University. Dr. Nguluma holds a Ph.D (Built Environment Analysis), from Royal Institute of Technology (KTH), Stockholm, Sweden

Her major fields of specialization are Architecture, Built Environment Analysis and Housing. She has carried out a number of research and consultancies to public, private and International Institutions, CBOs, and NGOs. She has also fairly published in the field of human settlements in local and international journals on various issues pertaining to housing transformation, spatial quality, construction industry, home based enterprises, and house types

Apart from Research and Consultancies, Dr. Nguluma offers lectures and dissertation/thesis coordination and supervision to undergraduate and postgraduate students in the Department of Architecture and Institute of Human Settlements Studies 